\title{
Epidemiology of bacterial diseases in Norwegian aquaculture-a description based on antibiotic prescription data for the ten-year period 1991 to 2000
}

\author{
A. Lillehaug ${ }^{1, *}$, B. T. Lunestad ${ }^{2}$, K. Grave ${ }^{3}$ \\ ${ }^{1}$ National Veterinary Institute, PO Box 8156 Dep., 00033 Oslo, Norway \\ ${ }^{2}$ Institute of Nutrition, Directorate of Fisheries, PO Box 185 Sentrum, 5804 Bergen, Norway \\ ${ }^{3}$ Department of Pharmacology, Microbiology and Food Hygiene, Norwegian School of Veterinary Science, \\ PO Box 8146 Dep., 00033 Oslo, Norway
}

\begin{abstract}
In Norway, antibacterial drugs for use in farmed fishes have to be prescribed by a veterinarian. Moreover, a national surveillance programme requires that copies of all prescriptions be sent to the Directorate of Fisheries. The prescriptions give information regarding fish farm and locality, weight and species of fish to be medicated, diagnosis, type and amount of drug prescribed, and date. These prescription data for the $10 \mathrm{yr}$ period 1991 to 2000 have been recorded and systematised. A total of 6322 prescriptions issued for 11 fish species were registered; Atlantic salmon represented $87 \%$ of the prescriptions, rainbow trout $4.5 \%$, arctic char $0.3 \%$, turbot $3.8 \%$, halibut $2.1 \%$, Atlantic cod $1.2 \%$, and European eel $0.3 \%$. European sea-bass, wolf-fish, coalfish and wrasse represented a total of $0.4 \%$ of the prescriptions. Furunculosis was the most frequently given diagnosis in Atlantic salmon, accounting for $79 \%$ of all prescriptions for this species. Furunculosis was more frequent during the summer and early autumn, and in the western parts of Norway. Fish weighing more than $1 \mathrm{~kg}$ seemed to be the most susceptible. However, furunculosis has almost disappeared in Norwegian aquaculture since 1993. Vibriosis gave cause for antibiotic treatments in almost all fish species, and was the most common diagnosis in rainbow trout, halibut, turbot, cod and European eel. In Atlantic salmon, fish of small and medium size (up to $1 \mathrm{~kg}$ ) seemed to be more at risk from vibriosis, and outbreaks were more frequent during summer, and in the western counties. Cold-water vibriosis was the second most frequently treated disease in Atlantic salmon, creating severe problems mainly in larger fish, in the northern parts of the country, and during winter and spring. The seasonal distribution was similar for winter ulcer disease, the only disease which seemed to be of increasing importance in Atlantic salmon. Non-specific diagnoses, such as 'bacterial infection' and 'fry disease', were given in a much higher proportion of prescriptions for marine fish species than in prescriptions for salmonids.
\end{abstract}

KEY WORDS: Aquaculture $\cdot$ Bacterial diseases $\cdot$ Epidemiology $\cdot$ Prescriptions Resale or republication not permitted without written consent of the publisher

\section{INTRODUCTION}

In fish farming, mortality due to infectious diseases has been considered to be a significant factor contributing to reduced production and profits. However, exact records of disease outbreaks, providing a basis for accurate assessment of different epidemiological aspects of such loss factors, are rare. Veterinary practitioners are obliged by law to report outbreaks of notifiable diseases to the authorities. However, it is not a requirement to report the extent of losses during such outbreaks and it is unlikely that infectious diseases considered to be of lesser importance are always reported. Moreover, there are many disease conditions comprising an infectious element that are not notifiable.

In Norway, all pharmaceuticals intended for therapeutic use in animals, including farmed fishes, must be prescribed by a veterinarian and dispensed from a pharmacy or, for medicated feed, from an authorised feed mill. On behalf of the Ministry of Health, the World Health Organisation Collaborating Centre for 
Drug Statistics Methodology in Oslo records overall sales volumes for drugs used in farmed fishes. Such data have been published previously (Grave et al. 1990, 1996). In order to support the control of residues of pharmaceuticals in fish products, a national surveillance programme was established in January 1989 (Bangen et al. 1994). This programme requires that copies of all prescriptions for drugs intended for use in farmed fishes be sent to the Directorate of Fisheries (DF), regional office, by the prescribing veterinarians, dispensing pharmacies and feed mills. Moreover, veterinarians are obliged to use an authorised prescription form on which information regarding fish farm identity and locality, type and amount of pharmaceutical preparation prescribed, weight and species of fish to be medicated, reason for treatment (diagnosis), and date for start of treatment must be provided. Although the application of this system is intended to ensure the absence of drug residues in fish for human consumption, these prescriptions also contain information about the epidemiology of the diseases being treated, which may be of value if systematised.

The aim of the present study was to use the information given on the prescriptions forwarded to the DF as a basis to describe the disease situation regarding bacterial infections in the different fish species in Norwegian aquaculture during the decade 1991 to 2000 .

\section{MATERIALS AND METHODS}

The 9 regional offices of the Directorate of Fisheries (DF) provided lists containing information given on the prescriptions of antibacterial drugs for farmed fishes forwarded by veterinarians during the period 1991 to 2000. The lists were electronic files or paper copies, and had been produced at the regional offices by data entry of the information given on the authorised prescription forms. They contained information regarding county of location of the actual fish farm, the species and weight of the fish to be treated, name and overall weight of the active drug substance, date of the start of treatment, and disease diagnosis. These data were entered into a Microsoft ${ }^{\circledR}$ Excel spreadsheet.

A total of 6322 prescriptions were reported to the DF during the period in question, and included in the study (see Table 1). Among the reported prescriptions, 222 had missing values for $1(n=207)$ or $2(n=15)$ variables. 'Fish weight' was lacking in 168 prescriptions, 'diagnosis' in 33 , 'fish species' in 26, and 'weight of drug substance' in 10 prescriptions, respectively. In all of the 15 prescriptions with 2 missing values, 'fish weight' was one of them. In 6 of the prescriptions lacking a diagnosis, 'bath treatment' was given instead of a diagnosis.
Irrelevant diagnoses (sea-lice or tapeworm), which are not indications for antibiotic treatment, were given in 13 of the prescriptions. These irrelevant diagnoses were probably due to mis-entry of data into the lists prepared by the DF. Information concerning date for the start of the treatment was too limited to determine month of treatment in 46 prescriptions.

The actual terms used for different diagnoses by the veterinarians filling in the prescriptions varied; some used the name of the bacterial species causing the disease outbreak, others used the designation of the disease. The terms used on the lists supplied by the DF also varied, and for the systematisation of the material, the treatments were categorized according to one of the following 21 standardised diagnoses:

Specific bacterial infections: Aeromonas hydrophila Atypical Aeromonas salmonicida Bacterial kidney disease (Renibacterium salmoninarum) Cold-water vibriosis (Vibrio salmonicida)

Furunculosis (Aeromonas salmonicida subsp. salmonicida)

Vibriosis (Vibrio anguillarum)

Winter ulcer disease (Vibrio viscosus, now Moritella viscosa)

Yersiniosis (Yersinia ruckeri)

Semi-specific diagnoses:

Aeromonas sp. infection

Flexibacter sp. infection

(now flavobacteria)

Pseudomonas sp. infection

Epitheliocystis

Fungal infection

Parasitic infections:

Hexamitosis

(now Spironucleus barkhanus)

Symptomatic diagnoses:

Bacterial gill disease

Fin rot/ulcers

Non-specific diagnoses:

Bacterial infection

Fry disease

Others:

Experiment

Prophylactic treatment

Predator wounds

In the present study, 1 treatment is defined as 1 prescription. For the description of geographical distribution of the infectious diseases in Atlantic salmon and rainbow trout, 'county treatment intensity' is given. This parameter is defined as the number of 
treatments prescribed in a certain county for a single diagnosis, divided by the number of fish farming concessions given in that county for the entire period. The DF provided information regarding the number of concessions by county at the end of each year for the production of Atlantic salmon and rainbow trout, distributed between freshwater and sea-water farms. Treatment intensity is given for the entire $10 \mathrm{yr}$ period; the total number of cases with the actual diagnosis in Atlantic salmon and rainbow trout is divided by the mean number of concessions during the period. In the present study, the diseases for which county treatment intensity has been calculated are exclusively 'sea-water diseases', and the number of concessions included relate solely to sea-water farming.

\section{RESULTS}

The total number of treatments with antibacterial drugs in Norwegian aquaculture was 1697 in 1991, reaching a maximum of 2751 in 1992 (Table 1). In 1993, the number of treatments decreased to 621, after which the annual number gradually declined to only 99 in 2000. This year-by-year variation mainly reflects the occurrence of antibiotic-treatable infectious diseases in Atlantic salmon, as $87 \%$ of the total number of treatments over the $10 \mathrm{yr}$ period was for this fish species. For other fish species, the total annual numbers of treatments showed less variation, declining gradually from 115 in 1991 to 37 in 2000. Prescriptions for rainbow trout comprised $4.5 \%$ of the total number, while those for turbot, halibut and Atlantic cod comprised $3.8,2.1$ and $1.2 \%$, respectively.

\section{Diagnoses in Atlantic salmon Salmo salar}

Of the 21 diagnoses registered in the present study, 19 were made in Atlantic salmon (Table 2), the only diagnoses not applied to this species being Aeromonas sp. infection and fungal infection. Furunculosis was by far the most frequently treated disease, accounting for $76 \%$ of the 5493 prescriptions, and was followed in decreasing order by the other specific bacterial infections, cold-water vibriosis (Vibrio salmonicida) representing $9.0 \%$, vibriosis ( $V$. anguillarum) $5.6 \%$, winter ulcer disease ( $V$. viscosus) $2.5 \%$, and yersiniosis ( $Y e r-$ sinia ruckeri) $1.0 \%$, respectively. On a drug weight basis, $79 \%$ of the total amount of antibiotics used in Atlantic salmon was for the treatment of furunculosis, $13 \%$ for cold-water vibriosis, $3.5 \%$ for vibriosis, $1.6 \%$ for winter ulcer disease and $0.26 \%$ for yersiniosis.

Aeromonas hydrophila, atypical A. salmonicida, bacterial kidney disease (Renibacterium salmoninarum), Flexibacter sp. and Pseudomonas sp. infection seldom gave cause for treatment in Atlantic salmon, while epitheliocystis required 17 treatments $(0.3 \%$ of total) (Table 2). The only parasitic disease for which antibiotic treatment is recommended, Hexamita salmonis, triggered 1 single treatment. There were relatively few prescriptions with symptomatic diagnoses, fin rot/ulcers representing $1.8 \%$ of treatments and bacterial gill disease $1.0 \%$. Prescriptions with the non-specific diagnoses bacterial infection and fry disease comprised $1.6 \%$ of the total.

Furunculosis outbreaks mainly occurred during the period 1991 to 1993, with $32 \%$ of treatments against this disease being carried out in 1991, $59 \%$ in 1992, and $8 \%$ in 1992 (Table 2). Thereafter, only a few, sporadic cases were registered. Treatments were most fre-

Table 1. Number of antibacterial treatments used in Norwegian fish farms during the period 1991 to 2000 as a function of fish species. Data were provided by the Directorate of Fisheries, and are based on information given by veterinary practitioners on prescriptions for antibacterial drugs

\begin{tabular}{|c|c|c|c|c|c|c|c|c|c|c|c|}
\hline \multirow{2}{*}{ Fish species } & \multirow[b]{2}{*}{1991} & \multirow[b]{2}{*}{1992} & \multirow[b]{2}{*}{1993} & \multirow[b]{2}{*}{1994} & \multirow[b]{2}{*}{1995} & \multirow{2}{*}{$\begin{array}{l}\text { Year } \\
1996\end{array}$} & \multirow[b]{2}{*}{1997} & \multirow[b]{2}{*}{1998} & \multirow[b]{2}{*}{1999} & \multirow[b]{2}{*}{2000} & \multirow{2}{*}{ Total } \\
\hline & & & & & & & & & & & \\
\hline Atlantic salmon & 1573 & 2633 & 538 & 134 & 233 & 93 & 73 & 80 & 74 & 62 & 5493 \\
\hline Rainbow trout & 20 & 39 & 26 & 35 & 44 & 33 & 38 & 11 & 27 & 11 & 284 \\
\hline Arctic char & 10 & 9 & 1 & & & & & 1 & & & 21 \\
\hline Halibut & 4 & 4 & 3 & 24 & 17 & 14 & 26 & 11 & 15 & 13 & 131 \\
\hline Turbot & 74 & 41 & 22 & 38 & 32 & 7 & 10 & 13 & 4 & 2 & 243 \\
\hline Atlantic cod & 7 & 14 & 11 & 9 & 7 & 7 & 6 & 3 & 2 & 7 & 73 \\
\hline European eel & & 2 & 14 & 1 & & 2 & & & & & 19 \\
\hline Wrasse & & & & & & & 7 & 2 & 3 & & 12 \\
\hline Sea bass & & 1 & & & & & & & & & 1 \\
\hline Wolffish & & 3 & & 2 & 2 & 1 & 1 & & 1 & 3 & 13 \\
\hline Coalfish & & & & & & & & & 1 & 1 & 2 \\
\hline Not given/other & 9 & 5 & 6 & 1 & & 3 & 1 & 1 & 4 & & 30 \\
\hline Sum & 1697 & 2751 & 621 & 244 & 335 & 160 & 162 & 122 & 131 & 99 & 6322 \\
\hline
\end{tabular}


Table 2. Salmo salar. Number of antibacterial treatments according to different diagnoses reported on prescriptions for Atlantic salmon in Norwegian fish farms during the period 1991 to 2000, giving weight limits for fish to be treated and month of the year of treatment. Prescription data were provided by the Directorate of Fisheries

\begin{tabular}{|c|c|c|c|c|c|c|c|c|c|c|c|c|c|}
\hline \multirow{2}{*}{ Diagnosis } & \multirow[b]{2}{*}{1991} & \multirow[b]{2}{*}{1992} & \multirow[b]{2}{*}{1993} & \multirow[b]{2}{*}{1994} & \multicolumn{2}{|c|}{ _Year } & \multirow[b]{2}{*}{1997} & \multirow[b]{2}{*}{1998} & \multirow[b]{2}{*}{1999} & \multirow[b]{2}{*}{2000} & \multirow{2}{*}{ - Total } & \multirow{2}{*}{$\begin{array}{c}\text { Wt }(\mathrm{g}) \text { of } \\
\text { fish treated } \\
(\mathrm{min}-\mathrm{max})\end{array}$} & \multirow{2}{*}{$\begin{array}{l}\text { Time of year } \\
\text { of treatment } \\
\text { (month) }\end{array}$} \\
\hline & & & & & 1995 & 1996 & & & & & & & \\
\hline Aeromonas hydrophila & & & & & 1 & & & & & & 1 & 50 & 9 \\
\hline Atypical A. salmonicida & 1 & & & & & & & & & & 1 & 2000 & 9 \\
\hline Bacterial kidney disease & 2 & & & & & & & & & & 2 & $72-1500$ & 5,6 \\
\hline Cold-water vibriosis & 43 & 86 & 145 & 52 & 141 & 24 & & 1 & 3 & 1 & 496 & $5-7500$ & All year \\
\hline Furunculosis & 1357 & 2470 & 341 & 9 & 8 & & & & 2 & 2 & 4189 & $1-22000$ & All year \\
\hline Vibriosis & 114 & 30 & 14 & 22 & 25 & 36 & 32 & 22 & 9 & 4 & 308 & $6-3000$ & All year \\
\hline Winter ulcer disease & 1 & 4 & & 5 & 8 & 13 & 25 & 26 & 27 & 28 & 137 & $45-4000$ & $1-6,10-12$ \\
\hline Yersiniosis & 30 & & 2 & 1 & & 1 & 3 & 7 & 7 & 4 & 55 & $1-650$ & $2,4-12$ \\
\hline Flexibactersp. infection & & & & 1 & 1 & & & & & & 2 & $130-300$ & 4,10 \\
\hline Pseudomonas sp. infectio & & & & 2 & & 1 & & & & & 3 & $40-120$ & 4,5 \\
\hline Epitheliocystis & & 2 & & 10 & 3 & & & & 2 & & 17 & $25-430$ & $1,2,7-11$ \\
\hline Hexamitosis & 1 & & & & & & & & & & 1 & 500 & 1 \\
\hline Bacterial gill disease & 7 & 15 & 13 & 5 & 9 & 2 & 4 & & 1 & & 56 & $1-4000$ & $1-6,8-11$ \\
\hline Fin rot/ulcers & & 3 & 3 & 13 & 19 & 6 & 5 & 20 & 11 & 21 & 101 & $10-1000$ & All year \\
\hline Bacterial infection & 13 & 17 & 9 & 9 & 15 & 3 & 2 & 3 & 10 & 1 & 82 & $1-12500$ & All year \\
\hline Fry disease & 1 & 3 & 2 & & & & & & & & 6 & $6-350$ & $1,2,7,12$ \\
\hline Experiment & & 1 & 7 & 2 & & & & & & & 10 & $15-1100$ & $2,3,5,7,10,11$ \\
\hline Prophylactic treatment & 1 & & & & & & & & & & 1 & 6 & 4 \\
\hline Predator wounds & & & & & & & & & & 1 & 1 & 100 & 12 \\
\hline $\begin{array}{l}\text { Missing/irrelevant } \\
\text { diagnosis }\end{array}$ & 2 & 2 & 2 & 3 & 3 & 7 & 2 & 1 & 2 & & 24 & $40-3500$ & All year \\
\hline Sum & 1573 & 2633 & 538 & 134 & 233 & 93 & 73 & 80 & 74 & 62 & 5493 & & \\
\hline
\end{tabular}

quent during the summer and early autumn, peaking in August (Fig. 1). Only $8 \%$ of the treatments were for fish of a size up to $100 \mathrm{~g}$, while as many as $54 \%$ were for fish weighing more than $1 \mathrm{~kg}$ (Fig. 2).

The proportion of treatments for cold-water vibriosis peaked at 29\% in 1993 and at 28\% in 1995 (Table 2). After 1996, a total of only 5 treatments for this disease was reported. The monthly distribution of outbreaks (Fig. 1) demonstrates an increasing occurrence from early autumn to late winter, with a minimum in September $(0.8 \%$ of the treatments) and a maximum in March (16\% of the treatments).

For vibriosis, it was found that the occurrence of treatments in Atlantic salmon was highest during the first study year (1991), covering $37 \%$ of all vibriosis treatments registered (Table 2). From 1992 onwards, the annual total of outbreaks of this disease remained fairly constant, although there was a tendency towards a decrease during the last couple of years of the study period. July was the month with the largest number of treated outbreaks (19\%) (Fig. 1), the number of outbreaks gradually decreasing to a minimum in March (2.3\%). Vibriosis was most frequently treated in small fish up to $100 \mathrm{~g} \mathrm{(32 \% )}$ and in medium-sized fish (59\%), while only few treatments were reported in fish of more than $1 \mathrm{~kg}$ (Fig. 2).

Yersiniosis gave rise to 55 treatments in Atlantic salmon. More than half of these were initiated in July
( $n=16)$ and August $(n=12)$. No outbreaks were reported in January and March. Relatively small fish were treated, only 10 treatments being for fish weighing more than $100 \mathrm{~g}$ (Fig. 2). The geographical distribution of this disease was limited to 2 counties; 13 treatments were in Nordland and 40 in Møre og Romsdal.

Winter ulcer disease was the reason for 137 treatments, of which 107 were initiated during December to March (Fig. 1). No treatments were recorded during July to September. Treated fish weighed from 45 to $90 \mathrm{~g}$ in 17 cases, and from 100 to $800 \mathrm{~g}$ in 98 cases. In the remaining 18 cases for which fish weights were given, fish weighed from 1 to $4 \mathrm{~kg}$. Winter ulcer disease showed an increasing importance in the study period, representing 18 treatments in the 5 yr period 1991 to 95, and 119 treatments from 1996 to 2000. The more symptomatic diagnosis fin rot/ulcers gave rise to 101 treatments, of which 64 cases were distributed relatively evenly between the months November to March (11 to 14 per month). The treated fish tended to be smaller in these outbreaks, being from 10 to $100 \mathrm{~g}$ in 42 cases, with only 1 treatment concerning a fish of $1 \mathrm{~kg}$. The latter diagnosis was also more common in the second half of the study period, being reported 38 times during the first $5 \mathrm{yr}$, and 63 times during the last $5 \mathrm{yr}$.

The symptomatic diagnosis bacterial gill disease ( $\mathrm{n}=56$ ), and the non-specific diagnoses bacterial 

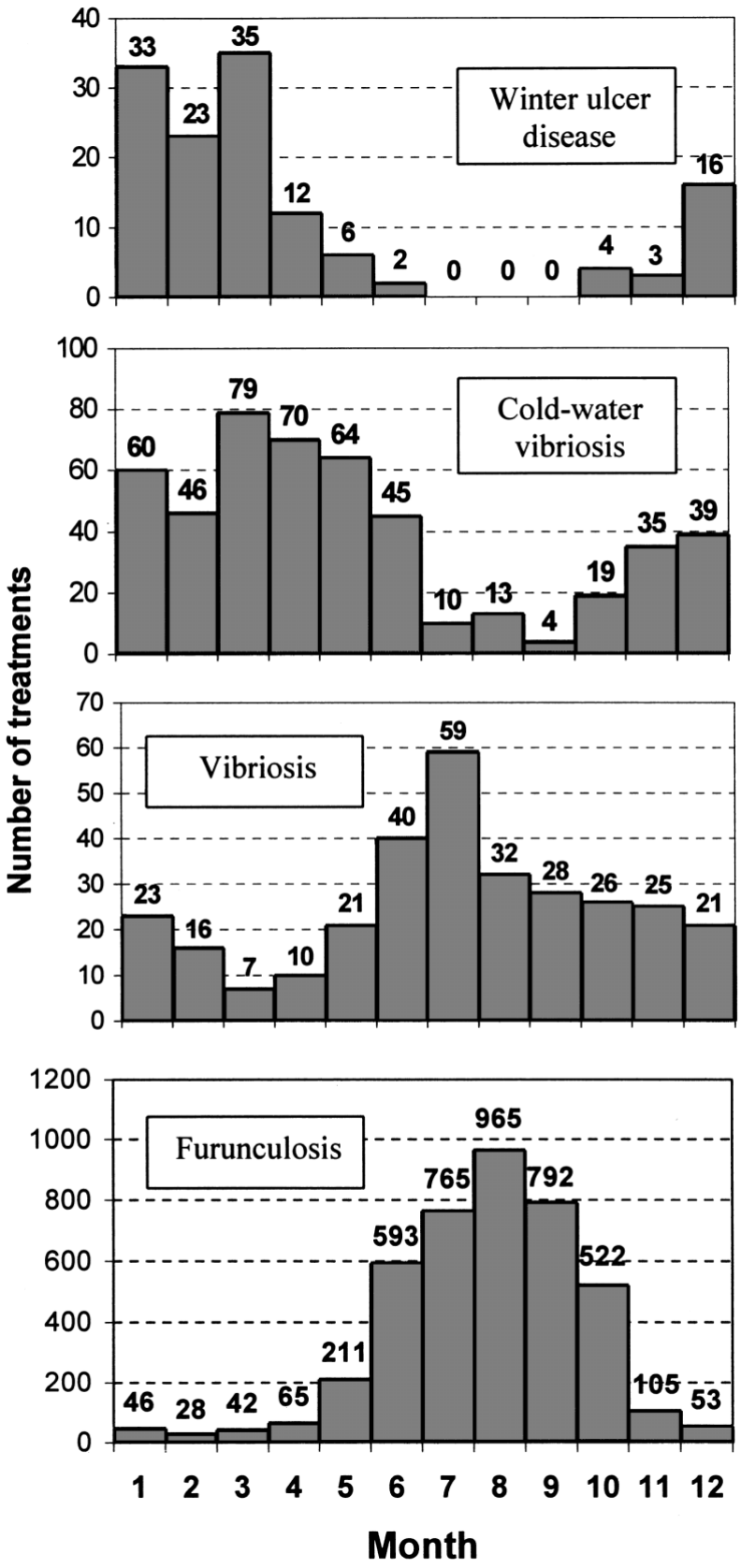

Fig. 1. Salmo salmar. Monthly distribution of treatments with antibacterial drugs against furunculosis, vibriosis, cold-water vibriosis and winter ulcer disease in Atlantic salmon in Norway during the $10 \mathrm{yr}$ period 1991 to 2000

infection $(n=82)$ and fry disease $(n=6)$ made up $2.6 \%$ of the treatments in Atlantic salmon. Both fry disease, requiring 5 treatments from December to February, and bacterial gill disease, requiring 44 treatments from January to May, tended to be more frequent during periods when water temperatures were low. Surprisingly, fry disease was reported in fish up to $350 \mathrm{~g}$, while bacterial gill disease appeared in fish from 1 to $100 \mathrm{~g}$ in 42 cases, and from 120 to $650 \mathrm{~g}$ in 9 cases. One prescription for the treatment of bacterial gill disease was for fish weighing $4 \mathrm{~kg}$. Bacterial infection was more frequently treated in the summer, 50 out of 79 cases being reported during May to September. The weight distribution of fish to which this diagnosis was applied was also quite evenly spread, with 40 cases concerning fish from 1 to $100 \mathrm{~g}, 22$ from 110 to $900 \mathrm{~g}$, and 14 from 1.2 to $12.5 \mathrm{~kg}$.

\section{Diagnoses in rainbow trout Oncorhynchus mykiss}

Vibriosis was by far the most frequent diagnosis in rainbow trout, giving rise to $80 \%$ of the 284 treatments. The numbers of cases were relatively constant from year to year (Table 3). The weights of the treated fish were from 8 to $100 \mathrm{~g}$ in 95 (44\%) cases, from 110 to $1 \mathrm{~kg}$ in $96(44 \%)$ cases, and from 1.2 to $2.5 \mathrm{~kg}$ in $26(12 \%)$ cases. Ten entries lacked values for fish weight. Although treatments were prescribed in all months, they were most frequent in July $(n=40)$, August $(n=47)$, September $(n=37)$ and October $(n=37)$.

Furunculosis gave rise to 28 treatments during the period 1991 to 1994. All outbreaks except one occurred during June to October. The fish treated were relatively heavy, with 18 treatments (64\%) for fish from $96 \mathrm{~g}$ to $1 \mathrm{~kg}$, and 10 treatments for fish of more than $1 \mathrm{~kg}$. Winter ulcer disease emerged as a diagnosis in rainbow trout in $1999(\mathrm{n}=4)$ and $2000(\mathrm{n}=2)$ in the county of Møre og Romsdal.

\section{Diagnoses in arctic char Salvelinus alpinus}

In Hordaland county, situated in the western part of Norway, 10 treatments for furunculosis were prescribed for arctic char weighing between 90 and $2800 \mathrm{~g}$, from May to September. Two treatments were also prescribed for furunculosis in the northern part of the country, where there were also 2 cases of atypical Aeromonas salmonicida in arctic char. These 4 cases were within the same range regarding fish weight and month of the year as the cases of furunculosis in Hordaland.

In 1991, 4 treatments for vibriosis were prescribed in July and August in fish weighing from 90 to $750 \mathrm{~g}$. The following reasons for treatment were reported once each in arctic char: bacterial gill disease, fry disease and experiment.

\section{Diagnoses in halibut Hippoglossus hippoglossus}

Of the 131 treatments reported (Table 1), as many as 51 related to diagnoses grouped as 'non-specific' 


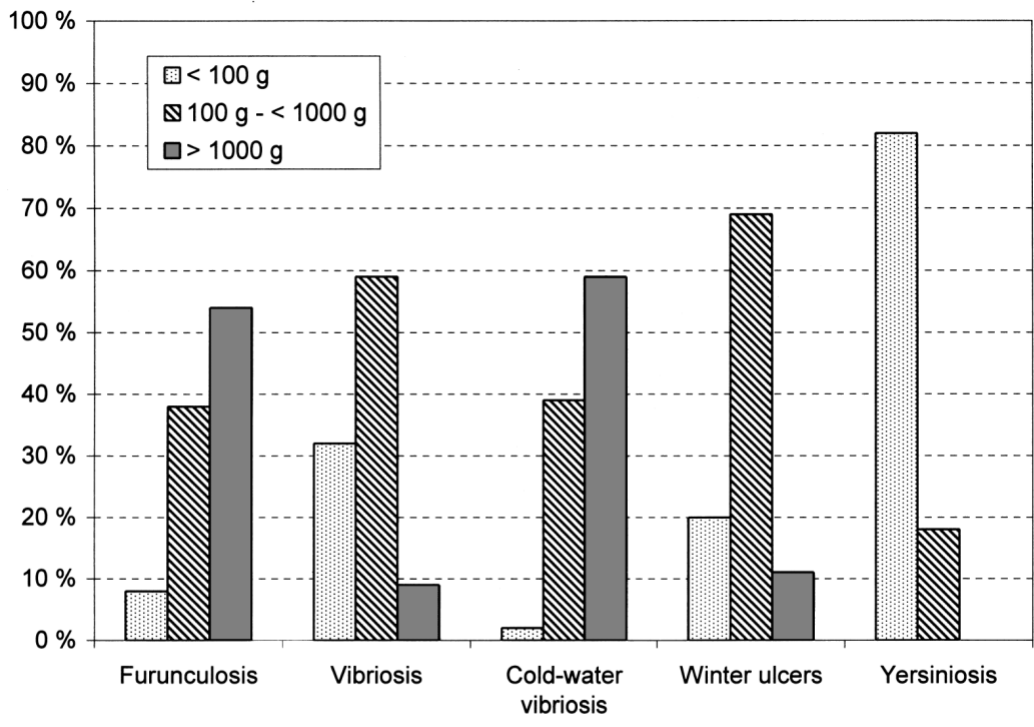

Fig. 2. Salmo salmar. Distribution of fish sizes of Atlantic salmon treated with antibacterial drugs against furunculosis, vibriosis, cold-water vibriosis, winter ulcer disease and yersiniosis in Norway during the 10 yr period 1991 to 2000 carried out in the summer: June $(\mathrm{n}=4)$, July ( $\mathrm{n}=9$ ), August $(\mathrm{n}=15)$, and September $(\mathrm{n}=5)$.

Of 14 treatments for disease caused by bacteria of the genus Aeromonas, 5 were for Aeromonas sp. infection, 6 for atypical A. salmonicida, and 3 for furunculosis. Fish size varied between $10 \mathrm{~g}$ and $5.6 \mathrm{~kg}$ in these outbreaks. Two cases of yersiniosis in halibut were treated in August and December 1999 in the county of Møre og Romsdal, in fish of 80 and $400 \mathrm{~g}$, respectively.

\section{Diagnoses in turbot Psetta maxima}

Altogether 243 treatments concerned turbot (Table 4). Of these, 193 took place in the county of Vest-Agder, where turbot fry production is a developed industry. Nearly all turbot fry ( $n=31$ ) or 'others' $(n=20)$, while for 14 treatments no diagnosis was given. The non-specific diagnosis bacterial infection was given in 27 prescriptions and fry disease in 4 . Nearly all these treatments were prescribed for small fish up to $10 \mathrm{~g}$, only 2 prescriptions for bacterial infection concerning larger fish $(200 \mathrm{~g}$ and $1 \mathrm{~kg}$, respectively). In 3 cases no diagnosis was given, while fish size was lacking for 16 prescriptions.

Vibriosis was the most frequently reported specific diagnosis in halibut, representing 46 treatments. Most of the outbreaks were in fish weighing up to $10 \mathrm{~g}$ ( $\mathrm{n}=26) ; 9(20 \%)$ prescriptions concerned fish of 10 to $100 \mathrm{~g}$, while 10 were for fish from $200 \mathrm{~g}$ to $5 \mathrm{~kg}(22 \%)$, the maximum weight of fish treated. In 1 prescription, the fish weight was not given. Most treatments were are exported to other countries with warmer sea water required for the production of market-sized fish.

Table 4 gives an overview of the diagnoses giving rise to antibiotic treatment in this fish species. Vibriosis seems to be the only disease causing serious problems (180 treatments), while atypical A. salmonicidainfection and furunculosis together caused 25 treatments. Other diagnoses led to only few and sporadic treatments during the entire $10 \mathrm{yr}$ period. The overall number of treatments per year declined from 1996 onwards.

Of the treatments against vibriosis, 89 (52\%) concerned fish weighing up to $10 \mathrm{~g}, 38$ (22\%) fish weighing 10 to $100 \mathrm{~g}$, 35 (20\%) fish from $100 \mathrm{~g}$ to $1 \mathrm{~kg}$, and 10 treatments $(6 \%)$ larger fish, $10 \mathrm{~kg}$ being the maxi-

Table 3. Oncorhynchus mykiss. Number of antibacterial treatments according to different diagnoses reported on prescriptions for rainbow trout in Norwegian fish farms during the period 1991 to 2000, giving weight limits for fish to be treated and month of the year of treatment. Prescription data were provided by the Directorate of Fisheries

\begin{tabular}{|c|c|c|c|c|c|c|c|c|c|c|c|c|c|}
\hline \multirow[t]{2}{*}{ Diagnosis } & \multicolumn{10}{|c|}{ - Year } & \multirow[t]{2}{*}{ Total } & \multirow{2}{*}{$\begin{array}{c}\text { Wt }(g) \text { of } \\
\text { fish treated } \\
(\min -\mathrm{max})\end{array}$} & \multirow{2}{*}{$\begin{array}{l}\text { Time of year } \\
\text { of treatment } \\
\text { (month) }\end{array}$} \\
\hline & 1991 & 1992 & 1993 & 1994 & 1995 & 1996 & 1997 & 1998 & 1999 & 2000 & & & \\
\hline Cold-water vibriosis & & & & & 1 & & & & & & 1 & 1100 & 5 \\
\hline Furunculosis & 4 & 19 & 4 & 1 & & & & & & & 28 & $96-3000$ & $1,6-10$ \\
\hline Vibriosis & 14 & 16 & 22 & 29 & 40 & 32 & 38 & 11 & 19 & 6 & 227 & $8-2500$ & All year \\
\hline Winter ulcer disease & & & & & & & & & 4 & 2 & 6 & $450-1000$ & 2,12 \\
\hline Bacterial gill disease & & 3 & & & 1 & & & & 1 & & 5 & $1-10$ & $4-6$ \\
\hline Bacterial infection & 2 & 1 & & 5 & & & & & 3 & 3 & 14 & $1-300$ & $3,5,7-11$ \\
\hline $\begin{array}{l}\text { Missing/irrelevant } \\
\text { diagnosis }\end{array}$ & & & & & 2 & 1 & & & & & 3 & $30-50$ & 3,12 \\
\hline Sum & 20 & 39 & 26 & 35 & 44 & 33 & 38 & 11 & 27 & 11 & 284 & & \\
\hline
\end{tabular}


Table 4. Psetta maxima. Number of antibacterial treatments according to different diagnoses reported on prescriptions for turbot in Norwegian fish farms during the period 1991 to 2000, giving weight limits for fish to be treated and month of the year of treatment. Prescription data were provided by the Directorate of Fisheries

\begin{tabular}{|c|c|c|c|c|c|c|c|c|c|c|c|c|c|}
\hline \multirow[t]{2}{*}{ Diagnosis } & \multirow[b]{2}{*}{1991} & \multirow[b]{2}{*}{1992} & \multirow[b]{2}{*}{1993} & \multirow[b]{2}{*}{1994} & \multicolumn{2}{|c|}{ - Year } & \multirow[b]{2}{*}{1997} & \multirow[b]{2}{*}{1998} & \multirow[b]{2}{*}{1999} & \multirow[b]{2}{*}{2000} & \multirow[t]{2}{*}{ Total } & \multirow{2}{*}{$\begin{array}{l}\text { Wt }(g) \text { of } \\
\text { fish treated } \\
(\mathrm{min}-\mathrm{max})\end{array}$} & \multirow{2}{*}{$\begin{array}{l}\text { Time of year } \\
\text { of treatment } \\
\text { (month) }\end{array}$} \\
\hline & & & & & 1995 & 1996 & & & & & & & \\
\hline $\begin{array}{l}\text { Atypical } \\
\text { Aeromonas salmonicida }\end{array}$ & 4 & & & & & & & 3 & & & 7 & $12-1000$ & $2,4,6,7,9$ \\
\hline Furunculosis & 12 & 6 & & & & & & & & & 18 & $20-10000$ & $1-3,7,8,10$ \\
\hline Vibriosis & 52 & 29 & 16 & 34 & 23 & 7 & 10 & 4 & 3 & 2 & 180 & $1-10000$ & All year \\
\hline Flexibacter sp. infection & & & & 1 & 4 & & & 2 & & & 7 & $1-200$ & $1,2,8-10$ \\
\hline Bacterial gill disease & 3 & & 2 & & & & & & & & 5 & $1-100$ & $3,5,8$ \\
\hline Fin rot/ulcers & 1 & & & 1 & & & & & & & 2 & $1-120$ & 4,10 \\
\hline Bacterial infection & & 6 & 1 & 2 & 1 & & & 2 & 1 & & 13 & $1-400$ & $1,3-8$ \\
\hline Fry disease & & & 3 & & 3 & & & & & & 6 & $2-5$ & $4-7$ \\
\hline $\begin{array}{l}\text { Missing/irrelevant } \\
\text { diagnosis }\end{array}$ & 2 & & & & 1 & & & 2 & & & 5 & $1-5000$ & $1-3,6$ \\
\hline Sum & 74 & 41 & 22 & 38 & 32 & 7 & 10 & 13 & 4 & 2 & 243 & & \\
\hline
\end{tabular}

mum weight. In 8 cases, fish weight was not specified. Monthly distribution of vibriosis-treatments varied from 7 in April to 25 in February and 29 in September. The number of monthly treatments otherwise ranged from 10 to 15 .

\section{Diagnoses in Atlantic cod Gadus morhua}

In cod, 73 treatments were reported (Table 1). Of these, 9 were for prophylactic treatment, and 6 for the non-specific diagnoses of bacterial infection and fry disease. Of the specific diagnoses, furunculosis was reported once in fish weighing $3 \mathrm{~g}$ in July 1992, and winter ulcer disease once in $300 \mathrm{~g}$ fish in February 1997. A total of 5 prescriptions were for the treatment of cold-water vibriosis, all in the period August to December.

The remaining 50 prescriptions were issued to tackle outbreaks of vibriosis. The annual number of treatments varied from $2(1994,1999)$ to $7(1995,1996$ and 2000). Fish size ranged from $1 \mathrm{~g}$ to $3 \mathrm{~kg}$, being $1 \mathrm{~kg}$ or more in 14 cases. Most of the outbreaks ( $\mathrm{n}=40$ ) occurred in counties in the western part of Norway; 31 in Hordaland, 8 in Møre og Romsdal, and 1 in Sogn og Fjordane. Mid-Norway experienced 3 outbreaks, and northern Norway 7 . Treatments were usually initiated in middle to late summer/early autumn, with peak intensity in July $(\mathrm{n}=11)$.

\section{Diagnoses in other species}

A total of 19 prescriptions was issued for the European eel Anguilla aguilla between 1992 and 1996
(Table 1), all of them in the county of Vest-Agder. In all cases but 1, the diagnosis was vibriosis, the exception being a case of fin rot/ulcers. These treatments were prescribed between April and October, and were evenly distributed between these months. Fish weights ranged from 5 to $200 \mathrm{~g}$, although only 3 prescriptions were for fish weighing less than $100 \mathrm{~g}$.

Altogether, 12 prescriptions were issued for the wrasse Labrus berggylta kept for biological delousing of salmonids in sea water (Table 1). For 9 treatments, the diagnosis was atypical Aeromonas salmonicida, all these treatments being carried out in the county of Møre og Romsdal. The remaining 3 treatments were carried out in Nordland, 2 for bacterial infection and 1 for prophylactic treatment.

For the wolf-fish Anarchichas lupus, 13 prescriptions were recorded (Table 1). In 6 cases, the diagnosis was furunculosis, in 4 cases atypical Aeromonas salmonicida, in 1 case vibriosis, and in 2 cases bacterial infection. The treatments were all in fish within a weightrange of 5 to $10 \mathrm{~kg}$, except for 1 furunculosis-case, which was in a fish of $300 \mathrm{~g}$.

One treatment of fry of the European sea-bass Dicentrarchus labrax was recorded in 1992, and 2 of the coalfish Pollachius virens in 1999 and 2000 (Table 1), respectively. The treatment in 1999 was against vibriosis in a $800 \mathrm{~g}$ fish. Four treatments were carried out on species declared as 'others'.

\section{County treatment intensities}

In this study, the geographical distribution of disease outbreaks of the 4 most important bacterial infections in salmonids - furunculosis, cold-water vibriosis, vibriosis 
and winter ulcer disease-is expressed as the mean number of treatments carried out per sea-water farm during the entire $10 \mathrm{yr}$ period 1991 to 2000 (Table 5).

The treatment intensity for furunculosis increased gradually from the northernmost county, Finnmark, with no treatments, to the 4 counties of western Norway, all of which experienced more than 8 treatments per sea-water farm during the $10 \mathrm{yr}$ period. The southernmost county in which salmonids are farmed in seawater, Vest-Agder, had a relatively low treatment intensity (1.29).

The geographical distribution for vibriosis was similar to that of furunculosis, with no treatments in Finnmark, and with the highest treatment intensity in the west coast counties. In contrast, cold-water vibriosis had a different geographical distribution, the highest treatment intensity being found in the northernmost counties, with a mean of 3.11 treatments in Troms, and 2.11 in Finnmark. The third northern county, Nordland, showed an intensity of approximately one-tenth compared to the 2 northernmost counties, while the other counties had a low intensity. There was 1 exception to this trend: Sør-Trøndelag in mid-Norway had on average 1.48 treatments per farm during the study period. Most of the treatments in Sør-Trøndelag were performed in 1995, the treatment intensity for coldwater vibriosis for that single year in the county being 1.38 .

Unlike the other 3 diseases, the treatment intensity for winter ulcer disease did not show any tendency towards a gradual south-north variation.

\section{DISCUSSION}

The present study describes the situation in Norwegian aquaculture regarding bacterial infections during the $10 \mathrm{yr}$ period 1991 to 2000. The positive development of a decline in the incidence of such diseases during this period has previously been documented by the use of drug sales statistics, which showed a 99\% decrease in overall consumption of antibacterial drugs in this industry during the 1990s (Grave et al. 1999). This has taken place despite a great increase in the production of farmed fishes in this decade (Table 6). This fact strengthens the conclusion regarding the improving infectious disease situation, because, other things being equal, it would be anticipated that the absolute number of cases of bacterial infections would be related to overall fish production.

The information given on the prescriptions for antibiotic treatments issued by veterinary practitioners makes it possible to keep records on the diagnoses giving rise to treatment in the different fish species. Moreover, the data provide information of epidemiological value regarding the characteristics of the different diseases, such as the size/generation of fishes suffering outbreaks, and the seasonal and geographical distribution of cases. Such features are already included in descriptions of the different infectious diseases, for example, in the textbooks of Roberts (1989), Inglis et al. (1993) and Austin \& Austin (1999). However, these descriptions are to a great extent based on experience and observation, while the results of the present study give a quantitative picture of the situation. In the following paragraphs, the main characteristics of outbreaks of the more important diseases are summarised.

Furunculosis was by far the most important disease in Norwegian aquaculture during the study period. This disease was diagnosed in $68 \%$ of all prescriptions, and the amount of antibiotics issued for its treatment comprised $77 \%$ of the total use of antibiotics for the whole period (data not shown). However, the problems

Table 5. Salmo salar and Oncorhynchus mykiss. County treatment intensity (mean number of treatments for each infection per sea-water farm) for 4 important bacterial infections in salmonids in Norwegian aquaculture during the period 1991 to 2000 . The number of sea-water farms represents the mean number of concessions per year for the period for each county. Prescription data and data on number of fish farm concessions were provided by the Directorate of Fisheries

\begin{tabular}{|c|c|c|c|c|c|}
\hline \multirow{2}{*}{ County } & \multirow{2}{*}{$\begin{array}{l}\text { Mean no. of sea-water } \\
\text { concessions per year } \\
\text { (max-min) }\end{array}$} & \multirow[b]{2}{*}{ Furunculosis } & \multirow{2}{*}{$\begin{array}{c}\text { Cold-wate } \\
\text { vibriosis }\end{array}$} & \multirow{2}{*}{ Vibriosis } & \multirow[b]{2}{*}{$\begin{array}{c}\text { Winter ulcer } \\
\text { disease }\end{array}$} \\
\hline & & & & & \\
\hline Finnmark & $49.2(34-73)$ & 0 & 2.11 & 0 & 0.16 \\
\hline Troms & $70.0(66-73)$ & 0.77 & 3.11 & 0.043 & 0.26 \\
\hline Nordland & $134.0(131-140)$ & 2.28 & 0.28 & 0.14 & 0.067 \\
\hline Nord-Trøndelag & $57.7(56-60)$ & 2.91 & 0.052 & 0.069 & 0.035 \\
\hline Sør-Trøndelag & $79.8(78-84)$ & 4.16 & 1.48 & 0.43 & 0.125 \\
\hline Møre og Romsdal & $107.6(102-115)$ & 9.54 & 0.019 & 0.33 & 0.47 \\
\hline Sogn og Fjordane & $74.2(73-75)$ & 8.79 & 0.013 & 1.29 & 0.23 \\
\hline Hordaland & $145.8(140-153)$ & 8.02 & 0.041 & 1.88 & 0.17 \\
\hline Rogaland & $56.3(54-61)$ & 8.76 & 0.11 & 1.15 & 0.053 \\
\hline Vest-Agder & $12.4(11-15)$ & 1.29 & 0.081 & 0.32 & 0 \\
\hline
\end{tabular}


Table 6. Production of farmed fishes in Norway during the period 1991 to 2000, based on figures generated by the Directorate of Fisheries. All figures are given as metric tons and measured as whole fish (ungutted) weight. 'Other species' includes turbot, wolf-fish, European sea-bass, European eel, coalfish and Atlantic mackerel

\begin{tabular}{|c|c|c|c|c|c|c|c|c|c|c|}
\hline \multirow{2}{*}{ Fish species } & & & & & & \multicolumn{5}{|c|}{ Year } \\
\hline & 1991 & 1992 & 1993 & 1994 & 1995 & 1996 & 1997 & 1998 & 1999 & 2000 \\
\hline Atlantic salmon & 155000 & 141000 & 163890 & 202470 & 261520 & 297560 & 332580 & 362430 & 418760 & 431740 \\
\hline Rainbow trout & 5700 & 6500 & 8970 & 14570 & 14700 & 22970 & 33300 & 48430 & 45280 & 49410 \\
\hline Arctic char & & 197 & 147 & 262 & 273 & 221 & 350 & 190 & 498 & 168 \\
\hline Halibut & & & 10 & 63 & 134 & 138 & 113 & 290 & 451 & 426 \\
\hline Atlantic cod & & 232 & 350 & 569 & 284 & 191 & 304 & 199 & 157 & 167 \\
\hline Other species & & & & 222 & 309 & 259 & 472 & 524 & 211 & 592 \\
\hline Total & 160700 & 147929 & 173367 & 218156 & 277220 & 321339 & 367119 & 412063 & 465357 & 482503 \\
\hline
\end{tabular}

caused by furunculosis were limited to the first 3 yr of the study period. After 1993, the disease literally disappeared, primarily due to the introduction of effective oil-adjuvanted vaccines in 1992 (Markestad \& Grave 1997). The present study shows that Atlantic salmon seem to be far more susceptible to furunculosis than rainbow trout, the second-most important aquaculture species in Norway. In 1992, the year with the highest incidence of furunculosis (Tables $2 \& 3$ ), the amount of antibacterial drugs used against the disease in these 2 species was 183 and $21 \mathrm{~g}$ per metric ton of fish slaughtered, respectively (antibacterial drug consumption data not shown; production data in Table 6). Furunculosis was also reported in turbot $(\mathrm{n}=18)$, arctic char $(\mathrm{n}=12)$, wolf-fish $(\mathrm{n}=6)$ and $\operatorname{cod}(\mathrm{n}=1)$.

Based on the data from prescriptions for Atlantic salmon, it seems clear that furunculosis, under Norwegian climatic and farming conditions, is a sea-water disease, the great majority of treated fish weighing more than $100 \mathrm{~g}$ (Fig. 2). The disease incidence varied with water temperature, being highest in August and lowest in February, with a gradual increase/decrease in incidence in the months between (Fig. 1). The differences in treatment intensities between counties (Table 5), with the highest intensities in western Norway (from Rogaland to Møre og Romsdal), and with decreasing intensities both towards the south (VestAgder) and the north, may also be explained by variations in water temperature.

Vibriosis seems to be the most important disease in Norwegian aquaculture, in the sense that it may affect many different fish species. In the present study, vibriosis was diagnosed and treated in almost all species included. It was the most frequently treated disease in rainbow trout (Table 3), halibut, turbot (Table 4), cod and eel, and the third-most common in Atlantic salmon (Table 2). Vibriosis was also registered in arctic char, wolf-fish and coalfish. In the light of the amount of antibiotics used against the disease, rainbow trout seem to be more susceptible than Atlantic salmon, an average of $4.5 \mathrm{~g}$ of antibacterial drugs being used against vibriosis in the former species per ton of fish produced during the $10 \mathrm{yr}$ period compared to $0.08 \mathrm{~g}$ in the latter species (data not shown). Nevertheless, the significance of vibriosis in salmonids also seems to have been decreasing, particularly during the latter part of the study period (Tables $2 \& 3$ ), this tendency being strengthened by the fact that there has been a steady increase in the production of fishes during the same period (Table 6). There is no obvious reason for this reduction in incidence.

Seasonal (Fig. 1) and geographical (Table 5) distributions of outbreaks of vibriosis in Atlantic salmon show similar patterns to those of furunculosis, indicating a preference for relatively high water temperatures. However, the maximum incidence occurs somewhat earlier in the summer (July). A totally different fish-size distribution was found for fish treated for vibriosis compared to those treated for furunculosis (Fig. 2), the majority of fish treated for vibriosis being small and medium-sized. These data support the observation that vibriosis causes the greatest problems during the first weeks after sea-transfer of the smolt. Such a seasonal variation was not seen in treatments of vibriosis in turbot, probably due to the fact that artificially heated water is used in turbot production in Norway.

Cold-water vibriosis was the second-most treated diagnosis in Atlantic salmon (Table 2). In addition, there were 5 treatments in cod and 1 in rainbow trout. There was a slight tendency towards an increase in the incidence during the first $5 \mathrm{yr}$ of the study period. While this disease had been more or less under control after the introduction of vaccines during the late 1980s (Press \& Lillehaug 1995), a relatively large number of outbreaks was registered in Sør-Trøndelag during the early and mid 1990s (data not shown). This was probably due to local implementation of sub-optimal vaccination procedures against the disease (Lillehaug 1996).

The seasonal distribution of treatments against coldwater vibriosis in Atlantic salmon showed a maximum 
in March, and low levels in July to September (Fig. 1). The county treatment intensities demonstrate the relatively great significance of the disease in the northernmost parts of the country, particularly Troms and Finnmark, and to some extent also Nordland. These findings underline the cold-water status of the disease, and probably to some extent also differences in the geographical distribution of the bacterium in the marine environment. The high treatment intensity in Sør-Trøndelag was probably due to the abovementioned sub-optimal vaccination practices. The size distribution of fish treated against cold-water vibriosis was quite similar to that of furunculosis, illustrating the sea-water status of the infection, as well as the susceptibility of fish during the entire sea-water rearing period.

Winter ulcer disease showed a tendency towards an increase in the number of cases in Atlantic salmon during the $10 \mathrm{yr}$ period (and to a lesser extent in rainbow trout), even though vaccines, based on antigens of Vibrio viscosus have been introduced in recent years (Greger \& Goodrich 1999). This disease, together with the symptomatic diagnosis fin rot/ulcers, which also involves ulceration of the skin, are the only 2 diagnoses in this study that showed a tendency towards an annual increase in absolute number of treatments. The clinical similarities between these 2 conditions are substantial, which implies that the diseases may have been mixed up in some cases. However, the diagnosis of winter ulcer disease should be based on the cultivation of $V$. viscosus. The general tendency of lower weights of fish treated for fin rot/ulcers indicates that the veterinary practitioners do distinguish between the diseases to a great extent.

There were no indications of regional differences in treatment intensities for winter ulcer disease. However, the overall number of treatments was too low to reveal any such differences. The size distribution of fish treated for winter ulcer disease was quite similar to that for vibriosis, indicating an increased susceptibility in fish during the first year in sea water. However, slaughtering of the entire population, rather than implementing antibiotic treatment, may have been used to handle this disease in market-sized fish, thus keeping these outbreaks out of the prescription statistics. The disease usually shows a chronic development and relatively low morbidity in affected populations (Lunder 1992), and these features may have forced the choice of such a strategy. Furthermore, the need to respect long withdrawal times after antibiotic treatment of fish during periods of low water temperature may have contributed to such a decision. Fig. 1 shows the high incidence of the disease during the winter months January to March; the disease never required treatment during July to September.
Yersiniosis was only recorded as a problem in Atlantic salmon (Table 2) (except for 2 treatments in halibut). The incidence of yersiniosis outbreaks was low and relatively stable (0 to 7 per year), except in 1991, the first year of the study period, when there were 30 treatments. More than $80 \%$ of the treatments were for fish weighing less than $100 \mathrm{~g}$ (Fig. 2), and field experiences in Norway have been of outbreaks in hatcheries and during the period immediately following sea transfer.

The proportion of non-specific diagnoses given showed a clear tendency to be much higher in marine fish species than in the salmonids (Atlantic salmon, rainbow trout and Arctic char). Bacterial infection and fry disease constituted $12 \%$ of the diagnoses in marine fishes, while $3.4 \%$ of the prescriptions for these species lacked a diagnosis. The proportion of prescriptions for salmonids with non-specific diagnoses or lacking a diagnosis were 1.8 and $0.3 \%$, respectively. The differences between salmonids and marine fishes in this respect are probably due to a generally higher competence and experience among veterinarians and fish farmers regarding health, disease and husbandry in the cultivation of salmonids. Marine fish farming is a much younger industry, at an earlier developmental stage, implying a lack of knowledge in fish diseases and poorer capacity of fish health laboratories.

The data used in this study were derived from the prescriptions issued by local veterinary practitioners. It has to be borne in mind that, in some cases, the prescription may have been dispensed before a laboratory had confirmed the microbiological diagnosis. Nevertheless, a preliminary laboratory result is often given, and the local veterinarian's evaluation of pathological findings together with knowledge of the epidemiological situation in the area give good reason to assume that the diagnoses in most cases are reliable.

The system of double reporting of the prescribing of drugs for farmed fishes, by the veterinarian on the one hand and by the pharmacy and feed mill on the other, ensures that all treatments are reported. However, during the actual registration of the data in this study, possibilities could have arisen for misunderstanding and erroneous entry of data in the databases. The prescription forms filled in by hand were read and entered at the Directorate of Fisheries, and much of the data was re-entered in the spreadsheet used in this study. However, the present description of the disease situation in Norwegian aquaculture during the 10 yr period in question is based on a large number of observations, and it is unlikely that a limited number of mistakes would influence the overall conclusions. The reliability of the results is verified by the fact that the total amounts of different types of antibacterial drugs used 
per year, as registered in the present material, correspond well with sales figures given by the drug wholesalers and the feed mills (Grave et al. 1999).

\section{CONCLUSION}

This study demonstrates that prescription data give important epidemiological information on the rates of treatment of different bacterial infections in fishes. This information includes the range of diseases in different fish species, the relative frequency of various diseases, and a description of the main features of disease outbreaks caused by bacterial infections, such as the size of fish affected, geographical distribution and seasonal variation.

\section{LITERATURE CITED}

Austin B, Austin DA (1999) Bacterial fish pathogens: disease of farmed and wild fish. Springer-Praxis Series in Aquaculture and Fisheries, 3rd edn. Springer Praxis, Chichester

Bangen M, Grave K, Nordmo R (1994) Description and evaluation of a new surveillance programme for drug use in fish farming in Norway. Aquaculture 199:109-118

Editorial responsibility: Chris Baldock, South Brisbane, Queensland, Australia
Grave K, Engelstad M, Søli NE, Håstein T (1990) Utilization of antibacterial drugs in salmonid farming in Norway during 1980-1988. Aquaculture 86:347-358

Grave K, Markestad A, Bangen M (1996) Comparison in prescribing patterns of antibacterial drugs in salmonid farming in Norway during the periods 1980-1988 and in 1989-1994. J Vet Pharmacol Ther 19:184-191

Grave K, Lillehaug A, Lunestad BT, Horsberg TE (1999) Prudent use of antibacterial drugs in Norwegian Aquaculture? Surveillance by the use of prescription data. Acta Vet Scand 40:185-195

Greger E, Goodrich T (1999) Vaccine development for winter ulcer disease, Vibrio viscosus, in Atlantic salmon, Salmo salar L. J Fish Dis 22:193-199

Inglis V, Robert RJ, Bromage, NR (1993) Bacterial diseases of fish. Blackwell Scientific Publications, Oxford

Lillehaug A (1996) Poor vaccination practises increased antibiotic use. Nor Fiskeoppdrett 21(7):24-25 (in Norwegian)

Lunder T (1992) 'Winter ulcer' in Atlantic salmon: a study of pathological changes, transmissibility, and bacterial isolates. Dr Sc thesis, Norwegian College of Veterinary Medicine, Oslo

Markestad A, Grave K (1997) Reduction of antibacterial drug use in Norwegian fish farming due to vaccination. Dev Biol Stand 90:365-369

Press CMcL, Lillehaug A (1995) Vaccination in European salmonid aquaculture: a review of practices and prospects. Br Vet J 151:45-69

Roberts RJ (1989) Fish pathology, 2nd edn. Baillière Tindall, London

Submitted: April 22, 2002; Accepted: September 18, 2002 Proofs received from author(s): December 9, 2002 